\title{
PET/CT Findings of a Patient with Striped Muscle Metastasis of Invasive Breast Carcinoma
}

\author{
Invaziv Meme Karsinomu Tanılı Hastanın PET/BT Görüntülemesinde Saptanan Çizgili Kas \\ Metastazı
}

\section{(1) Rabiye Uslu Erdemir1, (1) Özlem Elmas²}

IZonguldak Bülent Ecevit University Faculty of Medicine, Department of Nuclear Medicine, Zonguldak, Turkey

2Zonguldak Bülent Ecevit University Faculty of Medicine, Department of Radiation Oncology, Zonguldak, Turkey

\begin{abstract}
A 37-year-old female with a history of invasive breast carcinoma was referred to our department for an ${ }^{18}$ flor-fluorodeoxyglucose $\left({ }^{18} \mathrm{~F}\right.$-FDG) positron emission tomography/computed tomography whole-body scan. An intense ${ }^{18} \mathrm{~F}-\mathrm{FDG}$ uptake in striped muscles anterior to the left thigh region was noted. Excisional biopsy outcome from the left vastus medialis muscle was found to be consistent with striped muscle metastasis from breast carcinoma.
\end{abstract}

Keywords: Breast carcinoma, ${ }^{18} \mathrm{~F}-\mathrm{FDG}$ PET/CT, striped muscle, metastasis

\section{Öz}

Invaziv meme karsinomu tanılı 37 yaşında kadın hasta tüm vücut ${ }^{18}$ flor-florodeoksiglukoz ( ${ }^{18} \mathrm{~F}$-FDG) pozitron emisyon tomografi/bilgisayarlı tomografi görüntülemesi için birimimize başvurdu. Sol uyluk bölgesi anteriorundaki çizgili kaslarda yoğun artmış ${ }^{18} \mathrm{~F}-\mathrm{FDG}$ tutulumları saptandı. Bu bölgeden yapılan (sol vastus medialis kası) eksizyonel biyopsi sonucu meme karsinomu çizgili kas metastazı ile uyumlu olarak raporlandı.

Anahtar kelimeler: Meme karsinomu, ${ }^{18} \mathrm{~F}-\mathrm{FDG}$ PET/BT, çizgili kas, metastaz

Address for Correspondence: Asst. Prof. Rabiye Uslu Erdemir, MD, Zonguldak Bülent Ecevit University Faculty of Medicine, Department of Nuclear Medicine, Zonguldak, Turkey

Phone: +90 3722500329 E-mail: doktorhanim6@gmail.com ORCID ID: orcid.org/0000-0002-5542-7453

Received: 29.01.2020 Accepted: 06.05.2020

${ }^{\circ}$ Copyright 2021 by Turkish Society of Nuclear Medicine

Molecular Imaging and Radionuclide Therapy published by Galenos Yayınevi. 
A

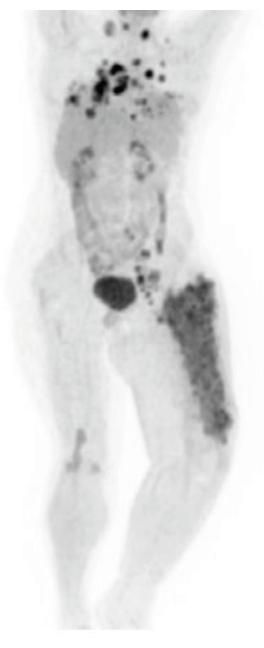

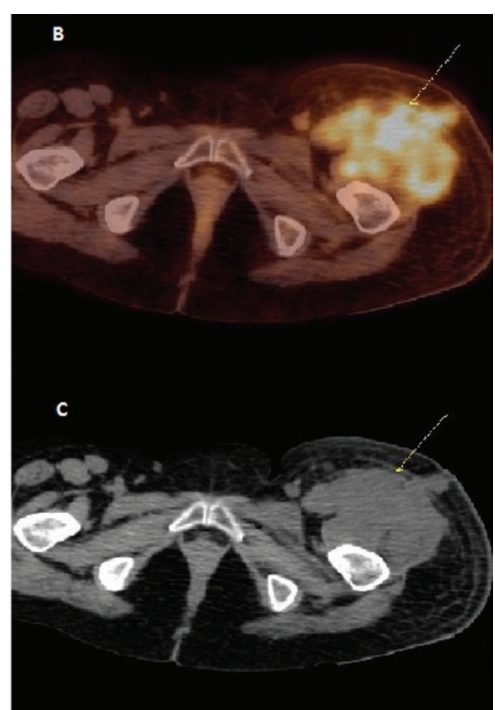

Figure 1. A 37-year-old female with invasive breast carcinoma was referred to our positron emission tomography/computed tomography (PET/CT) department for re-staging. Her medical history revealed a radical mastectomy for breast carcinoma in the left breast 2 years ago. The patient received chemotherapy and radiotherapy 1 year ago. The ${ }^{18}$ fluorine-fluorodeoxyglucose ( ${ }^{18} \mathrm{~F}-\mathrm{FDG}$ ) PET/CT scanning was performed 60 minutes after IV injection of $395 \mathrm{MBq}{ }^{18} \mathrm{~F}-\mathrm{FDG}$, on an integrated 16 slice PET/CT, scanning from the base of the skull to the knee. The obtained images from ${ }^{18} \mathrm{~F}-\mathrm{FDG}$ PET/CT maximum intensity projection (A), axial fusion (B), and axial CT (C) showed tracer accumulation in the striped muscles anterior to the left thigh region (maximum standard uptake value, 7.1; mean density, 8 Hounsfield units) (B, C yellow arrows). Excisional biopsy indicated striped muscle metastasis from breast carcinoma in the left vastus medialis muscle. Furthermore, radiation therapy application was started.

Although muscle tissue makes up approximately half of the total body weight, metastatic extension to the skeletal muscle is an exceptional event in neoplasms, with an incidence of $0.8 \%-1.5 \%$ in autopsy series $(1,2,3,4)$. Muscular contractile actions, lactic acid accumulations, and protease inhibitors affect the blood flow and inhibit the growth of tumor cells in the muscles. This potentially explains the rarity of this phenomenon (5). However, it has been reported that the incidence of metastasis is increased in trauma patients. In trauma, skeletal muscle function is impaired and focal hyperemia occurs, resulting in decreased ability of the muscle to eliminate lactic acid and increased possibility of metastatic cells to settle in the muscle. Therefore, patients should be assessed for trauma and hematoma and muscle rupture, and infection should be considered in differential diagnosis (6). Despite these protective mechanisms, soft tissue (striated muscle) metastasis secondary to lung cancer, kidney cancer, and colon cancer were reported in the literature (7). Intramuscular metastases can be seen in advanced and poorly differentiated tumors and worsen prognosis (8).

\section{Ethics}

Informed Consent: Consent was obtained patient.

Peer-review: Externally peer-reviewed.

\section{Authorship Contributions}

Concept: R.U.E., Design: R.U.E., Data Collection or Processing: R.U.E., Analysis or Interpretation: R.U.E., Literature Search: Ö.E., Writing: R.U.E., Ö.E.

Conflict of Interest: No conflict of interest was declared by the authors.

Financial Disclosure: The authors declared that this study received no financial support.

\section{References}

1. Damron TA, Heiner J. Distant soft tissue metastases: a series of 30 new patients and 91 cases from the literature. Ann Surg Oncol 2000;7:526534.

2. Pop D, Nadeemy AS, Venissac N, Guiraudet P, Otto J, Poudenx M, Mouroux J. Skeletal muscle metastasis from non-small cell lung cancer. J Thorac Oncol 2009;4:1236-1241.

3. Tuoheti Y, Okada K, Osanai T, Nishida J, Ehara S, Hashimoto M, Itoi E. Skeletal muscle metastases of carcinoma: a clinicopathological study of 12 cases. Jpn J Clin Oncol 2004;34:210-214.

4. Sridhar KS, Rao RK, Kunhardt B. Skeletal muscle metastases from lung cancer. Cancer 1987;59:1530-1534.

5. Acinas García O, Fernández FA, Satué EG, Buelta L, Val-Bernal JF. Metastasis of malignant neoplasms to skeletal muscle. Rev Esp Oncol 1984;31:57-67.

6. Magee T, Rosenthal H. Skeletal muscle metastases at sites of documented trauma. AJR Am J Roentgenol 2002;178:985-988.

7. Damron TA, Heiner J. Management of metastatic disease to soft tissue. Orthop Clin North Am 2000;31:661-673, ix.

8. Emlik D, Gök M, Ödev K, Kıreşi DA. Akciğer malign tümörüne bağlı iskelet kası metastazı. Selçuk Tıp Der 2005;21:25-28. 